\title{
SOCIOLOGICAL INTERVENTIONS FROM THE MARGINS
}

\section{STANIS ŁAW OSSOWSKI, STANISŁAW OSSOWSKI W PEŁNYM BLASKU. SUPLEMENT DO „DZIEt”, ED. ANTONI SUŁEK}

Friedrich Cain

Erfurt University

Late in 1961, Polish sociologist Stanisław Ossowski finished an essay on freedom of speech in the sciences. It would live to have a long publication history. In socialist Poland, where rigid controls were reimposed following the period of thaw after Stalin's death, Ossowski could not find a publisher, and so the text predicted its own fate: "If a scholar is deprived of freedom of speech, he either becomes a clerk, a player, or a conspirator" (Ossowski 2016: 215). ${ }^{1}$ Much like the latter, the essay moved underground. As it could not appear in any official Polish magazine in the early 1960s, typescript copies circulated throughout Warsaw. In 1977, a journal operating beyond censorship made it available to a broader public. Through the 1980s, that is, the times of Solidarity and martial law, the essay was printed in further (semi-)official publications. In 2016, it finally made its way into the volume that is being reviewed here: the Supplement to Stanisław Ossowski's collected works, which assembles critical or (assumedly) marginal texts that were not part of the six volumes published between 1966 and 1970.

The volume contains some forty-five texts covering a time span of about fifty years. Given Poland's fateful history, they were written under various regimes. Born in 1897 under Tsarist rule, Stanisław Ossowski went to study philosophy in Vilnius and Warsaw. The first text in the volume,

${ }^{1}$ All translations from Polish are my own. 
from 1916, is an early contemplation on philosophy's role in everyday life (Ossowski 2016: 23). Nine years later, Ossowski received a doctoral degree from Warsaw University, which by then was no longer part of (Soviet) Russia but right in the middle of the capital of the II Polish Republic (19181939). In the following years, Ossowski turned to sociology as the result of two longer research trips - the first leading him to France in the early 1920s, and the second to London in the 1930s. Up until the Second World War, he was developing some of the central motifs, terms, and subjects that would guide his further work. Social bonds in modern societies were one of his central focuses, but he was also interested in the conceptual history of social stratification, which he traced through the history of social theory all the way back to antiquity. Owing to his lifelong belief in enlightened humanity, Ossowski never stopped thinking about the social status of scientific research and researchers themselves. Science (and the humanities) could and should help to build a just and equal social life. ${ }^{2}$ In this respect the initial quote can stand as a motto for Ossowski's thought.

In autumn 1939, Ossowski feared German persecution and left for the Soviet occupied city of Lwów. Upon his return to Warsaw in 1941, he joined Polish resistance circles. Shortly after the war, he helped build a new university in the city of Lódź, before gaining a professorship at Warsaw University. Around 1950, he and other sociologists were banned from official teaching for several years, which drove him into opposition circles, again. Later, he would go on two research trips to the United States, before he died in Warsaw in 1963. His organisational and didactic efforts were crucial to the development of post-war sociology in Poland and increased his role as a figurehead of Polish, and specifically Varsovian, sociology (see Sułek 2014).

From his early studies in aesthetics and semiotics, Ossowski had a strong inclination to observe social phenomena; his interest eventually caused him to turn to the still emerging discipline of sociology. Having dealt with the mutual relations of art and societies in his early publications, he outlined subjects for his further works. This transition is central in the first sections of the Supplement, which contain several texts concerning the relations between religion, the nation, and revolution. These early writings not only give an insight into the mindset of the sociologist-to-be, they could also be a foundation stone for a broader intellectual history of interwar Poland, and especially of the leftist search for a position between Soviet radicalism and the project of a nation state.

\footnotetext{
${ }^{2}$ For an English overview of Ossowski’s works and central ideas, see Chałubiński 2006.
} 
Following the texts revealing Ossowski's intellectual coming-of-age as a sociologist, the volume's five remaining sections contain a broad range of genres and topics. The editor, Antoni Sulek, has organised them into two sections of commentary on public issues, two sections for academic sociological texts, and one for correspondence. The first section, with comments on public issues, assembles texts from the interwar period up to the early years after the Second World War. At that time, nationalism and social psychology were among Ossowski's central interests. He was intrigued by the integrative powers of national and genetic categories or metaphors and what he called their flipside, namely chauvinism and anti-Semitism. Here, the sociological analysis of the anti-Jewish pogrom in Kielce is especially interesting (Ossowski 2016: 104-113). In July 1946, a Polish mob killed more than forty Jewish people who had survived the German occupation. Afterwards, many other Holocaust survivors took this incident as a signal to leave the country, for anti-Semitism did not seem to have been overcome in a greater part of Polish society. Ossowski's text, in which he considers actual backgrounds and contemporary interpretations shortly after the events, is still awaiting an English translation, and might very well contribute to current (inter)national discussions.

The second section on public issues covers texts from the period of the thaw until the early 1960s. Here the overarching theme is freedom - freedom of speech in particular - and its importance to modern societies. As the initial quote (taken from this section) already implies, Ossowski took considerable interest in a broad sociology of science, which would cover both the exact disciplines and the humanities.

The first of the two sociological sections contains a broad variety of project outlines: there are concepts for small-scale research, and organisational plans for Polish universities, and especially for sociology. Ossowski was also keen to secure a place for Polish sociology in international networks, as his thoughts on Polish contributions to the International Sociological Association (ISA) show. Ossowski was present at the first ISA congress in Oslo (1949) and even served as vice-president between 1959 and 1962. The second sociological section contains two expert reports which Ossowski wrote for legal proceedings: for example, a report on the writings of the Jehovah's Witnesses (1959). The final section on correspondence allows for yet another insight into the breadth and depth of Ossowski's interests. Both the letters he exchanged with Bertrand Russell in 1922 and his later correspondence with fellow Polish sociologists show his broad intellectual, organisational, and political undertakings. 
The volume does indeed supplement the whole series of Ossowski's collected works. As has been mentioned, the first volume of the series treats of aesthetics, the second of nationalism, and the third contains studies on social psychology. The fourth deals with the sociology of science, or, more specifically, with knowing and learning; the fifth volume contains writings on social structure; and the formerly final, sixth volume assembles shorter texts from academia and beyond. ${ }^{3}$ Given this classification, the volume under scrutiny here is at odds with its predecessors. Rather than reproducing the scheme of the foregoing volumes, the collection attempts to develop its own narrative by linking the various fields of action. As the title says, the aim is to show Ossowski's "full splendour" (Pol. petny blask).

In his introduction, the editor, Antoni Sułek - himself a sociologist at Warsaw University and institutional "heir" to Ossowski - recounts the history of his academic forebear's published and unpublished works. He elucidates the difficulties of academic publishing under successive political systems and varying censorship regimes. While the larger part of Ossowski's output is contained in volumes one to six, the Supplement is intended to provide texts whose subjects involve the intersections of scholarship, research policy, and society. Ossowski's literary capabilities are revealed in a voice that moves from subtle critique to pragmatic intervention to open outrage at times. Owing to the genre of the collected works, Ossowski is presented with great fondness. The selection and introduction of the texts has been thoughtful, however, and so the collection could also be useful for readers from outside the field of sociology. For instance, as the editor himself suggests in the introduction, the initial coming-of-age sections will be interesting for intellectual biographers (Ossowski 2016: 12, 18).

As has been mentioned before, there are specific histories to certain of the texts. The status of some was opaque and volatile for many years (occasionally for decades) owing to the many different political situations. At times, Ossowski himself would republish a text (see Ossowski 2016: 214); others were rediscovered by movements, groups, or editors. Such textbiographies are not only illustrative examples for students of recent social history, but could also provide important source material for a cultural history of sociology in Poland, and especially in Warsaw. After all, Ossowski was part of several academic circles. Initially he frequented the Philosophy Students' Club at Warsaw University (see Ossowski's report on its proceed-

\footnotetext{
3 The collected works were published by a committee of friends and colleagues (including Ossowski’s wife, the philosopher Maria Ossowska) through Państwowe Wydawnictwo Naukowe in Warsaw (Ossowski 1966-1970).
} 
ings (2016: 46-60)). Later he was an active member in the Science of Science Club that met in Warsaw between 1928 and 1939 to discuss all kinds of research into knowing, learning, and teaching. After the war he was part of the Crooked Wheel Club, ${ }^{4}$ where eminent intellectuals discussed art, culture, politics, and philosophy (see Ossowski 2016: 193-203).

The volume contains rich material for studies in the rhetoric or practice of science and the humanities. Great effort was put into the careful editing of the texts, making them worthy sources for studying the literary and social practices of (academic) publishing. The edition expands former published versions of some of Ossowski's texts, taking into account penultimate manuscripts, censored typescripts, and drafts with comments (see, e.g., Ossowski 2016: 193). More than ever before, the publishing histories and connections to Ossowski's unpublished materials are mentioned in footnotes and editorial introductions. In this manner, the volume, which concentrates on obscure and preliminary texts, helps the reader to grasp the breadth of practical work occurring in academia and its many intersections with other systems of modern society. It is also very worth mentioning that the philosopher Maria Ossowska, the author's wife and lifelong collaborator, is granted more space in the editorial notes than ever before.

However, even this volume cannot fill all the gaps in the publication of Ossowski's works; further publications are to be expected, for example, Ossowski's diaries. ${ }^{5}$ Nevertheless, the volume should contribute to discussions of the early twenty-first century. Coming back to the initial quote again, what was (and is) at stake is precisely the academic worker's social status and responsibility. The volume presents us with several examples of the ever-growing entanglement of research and political, social, religious, or economic beliefs. While telling these areas apart might have been difficult for commentators of classical modernity, the postmodern jungle of socio-economics and social theory has rendered it almost impossible. To define the borders of functional social systems, discourses, or whatever the methodological approach might be has become increasingly hard: separating the overwhelming masses of communicative acts and social situations

\footnotetext{
${ }^{4}$ Ossowski was part of the first (Koło Filozoficzne Studentów Uniwersytetu Warszawskiego) when he was a student. He joined the second (Koło Naukoznawcze, 1928-1939) when he worked as a teacher and at Warsaw University. He was a member of the third (Klub Krzywego Koła, 19551962) after the Second World War.

${ }^{5}$ Both the Supplement and the publication of the diaries are part of a project funded by the Polish Ministry of Science and Higher Education ("W kręgu Stanisława Ossowskiego. Warszawska szkoła socjologii"). Much more material is stored at the joined libraries of the Faculty of Philosophy and Sociology of Warsaw University and the Polish Academy of Sciences in Warsaw. The correspondence of Ossowski and his wife have been published elsewhere: see Ossowska \& Ossowski 2002.
} 
has become impossible; the overarching guidelines keep falling apart. Ossowski's observations can help us to think about these theoretical and cultural developments.

The text about freedom of speech was directed at a very similar point. Ossowski meant to intervene not only in science policy but in society at large. Yet, rather than taking aim at the politics of ambiguity, or - anachronistically speaking - fake news and alternative facts, he was interested in the uncanny situation of a society parted into "Us" and "Them," devoid of ethics. Against the political and socio-economic upheavals of his time, which, of course, were also intellectual earthquakes, he kept dreaming about saving mankind through universal humanism.

Some texts in the volume share the freedom of speech as a central topic and even refer to each other. In "Taktyka i kultura" [Tactics and Culture, 1956, Ossowski 2016: 181-192), Ossowski envisioned a system of democratic participation; it had to be liberated from any kind of rule by the few, that is, by parties or classes. Such rule would hinder democratic discussion and confuse society with "social fictions." Even if these did not necessarily find full acceptance or belief, they would influence public life. Ossowski used metaphors of the theatre and the mask to describe the frictions between the public and the private spheres, and how this would undermine the development of democracy all together. Ossowski's answer was perhaps too optimistic: in order to solve the truth problem (especially simultaneous truth claims from counter-movements of all sorts), only free and just discourse would suffice. Here sociology became part of society. First it should help to describe problematic social situations and then it should assist in improving them. Scholars had to find a place in society in order to work for it - which has always been a problem for them, whether now or in the past.

Thus, apart from the historical or systematic interests that are addressed, the volume once again showcases one of Ossowski's central traits. He always tried to speak as a sociologist based in society, without parting the citizen from the researcher. In this respect the volume not only contributes to the genealogy of current discussions, but also reminds us of the need to be aware of the relationship between democratic societies and their (social) sciences. 
Bibliography:

/// Chałubiński M. 2006. "The Sociological Ideas of Stanisław Ossowski: His Life, Fundamental Ideas and Sociology in Polish and World Science," Journal of Classical Sociology, vol. 3, pp. 283-309.

/// Ossowska M., Ossowski S. 2002. Intymny portret uczonych. Korespondencja Marii i Stanisława Ossowskich, ed. E. Neyman, Wydawnictwo Sic!.

/// Ossowski S. 1966-1970. Dǐieła, 6 vols, Państwowe Wydawnictwo Naukowe

/// Ossowski S. 2016. Stanistaw Ossowski w petnym blasku. Suplement do „Driet”, ed. A. Sułek, Wydawnictwo Naukowe Scholar.

/// Sułek R. 2014. "Promieniowanie Stanisława Ossowskiego," [in:] Ossowski zperspek.tywy pótwiecza, ed. A. Sułek, Oficyna Naukowa, pp. 208-241.

/// Friedrich Cain - he is currently working at the Max Weber Center for Advanced Cultural and Social Studies at Erfurt University (Germany). In February 2018, he defended a doctoral thesis on the underground research of Polish scholars under German occupation during the Second World War. One part of the thesis specifically deals with Stanisław Ossowski's wartime studies. Cain has a strong interest in the history of science and the humanities, historical epistemology, and history-of-science studies. He was a co-organiser of the workshop "Political Epistemologies of (Eastern) Europe" in November 2017 and a co-editor of the volume A New Organon: Science Studies in Interwar Poland (with Bernhard Kleeberg, forthcoming 2018).

Email: friedrich.cain@uni-erfurt.de 
